\title{
Escalonamento em Redes de Missão Crítica
}

\author{
Sergio dos S. C. Silva, Ronaldo M. Salles, Paulo C. S. Vidal, Rafael D. Ribeiro \\ Seção de Engenharia de Computação - SE/8 \\ Rio de Janeiro, R.J., Brasil. E-mail:\{scardoso,salles,vidal,rdribeiro\}@ime.eb.br
}

\begin{abstract}
Scheduling mechanisms for critical operations over low performance wireless networks use of priorities to guarantee to the most valuable information the available communication resources to accomplish the mission. A traditional way to implement that is to use strict precedence levels, however such naive scheme has several side effects. We propose a multiple criteria decision approach which takes into account several parameters to make a decision. A lexicographic algorithm and an algorithm based on the barrier function are also proposed. Simulation results confirm the advantages on using our approach over traditional methods.
\end{abstract}

Resumo-Os algoritmos de escalonamento de mensagens para operações críticas sobre redes sem fio de baixo desempenho priorizam as mensagens a fim de garantir que a informação mais importante tenha os recursos suficientes para ser enviada. A forma tradicional de se implementar prioridades é através do emprego de filas de prioridades, contudo este esquema apresenta várias desvantagens. $O$ artigo propõe dois algoritmos multicritério para a realização do escalonamento das mensagens: o primeiro baseado na ordenação lexicográfica e o segundo no uso de funções barreira. Resultados de simulação confirmam o bom desempenho de nossas propostas em comparação com os algoritmos tradicionais.

\section{INTRODUÇÃO}

Apesar do desenvolvimento de tecnologias de rede sem fio mais eficientes, tais como IEEE 802.11 e IEEE802.16, que propiciam maior largura de banda e menor taxa de erros, existem cenários nos quais essas redes não podem ser empregadas. Isso ocorre em regiões como a Amazônia, devido as suas características geográficas, como a dimensão, a vegetação e as chuvas. Ainda podemos citar as situações de desastres ou calamidades quando a infra-estrutura de telecomunicações pode ter sido parcialmente ou totalmente destruída e o uso em operações militares.

Para esses cenários as opções de meios de comunicação são restritas e estão baseadas principalmente no uso de redes de satélites ou redes HF. Estes meios tornam-se eficazes porque podem cobrir distâncias maiores, ultrapassar obstáculos naturais, os equipamentos são portáveis podendo funcionar com baterias ou pequenos geradores, além de permitirem integração com redes IP [10] [11] [2] [14].

Porém, o uso de comunicações por satélite disponíveis no Brasil está baseado em equipamentos internacionais, o que não é adequado para empregos em situações de garantia da segurança nacional, além do custo de operação ser muito alto.

Dessa forma, o meio de comunicação viável para o emprego imediato nessas situações é a utilização de redes HF, que têm um custo baixo, tanto para a compra de equipamentos, quanto para operação da rede, podem ser rapidamente colocadas em operação, não necessitam de linha de visada e possuem longo alcance.
O emprego das redes HF pode ser destacada por exemplo, durante as operações de salvamento após o ataque de 11 de setembro em Nova Iorque onde a infra-estrutura de telecomunicações entrou em colapso devido à falta de energia, a destruição parcial das redes e o congestionamento causado por milhares de chamadas simultâneas.[10]

Apesar das vantagens da tecnologia HF, existem diversas restrições ao seu uso, tais como: baixa largura de banda, alta taxa de erros e alta latência, o que levam a rede a operar em sobrecarga. Desta forma, faz-se necessário o emprego de mecanismos de prioridade para garantir a transmissão das mensagens de maior importância fazendo com que o sistema cumpra a sua finalidade.

É importante destacar que em redes de missão crítica (ex. redes militares), de forma diferente das redes tradicionais, a qualidade de serviço (Quality of Service - QoS) oferecida no sistema deve ser controlada em função do valor do conteúdo das mensagens, ou seja, de acordo com a importância de cada transmissão para o cumprimento da missão [7].

Em redes militares, a forma tradicional de se implementar prioridades é através do emprego de filas de prioridades dividas em quatro categorias: Urgentíssima, Urgente, Prioridade e Rotina. Contudo o uso da precedência como o único critério de classificação pode impactar severamente a transmissão de mensagens de menor prioridade especialmente nos enlaces sem fio de baixo desempenho.

O presente artigo propõe o uso de algoritmos de decisão multi-critério que considera uma série de fatores na realização do escalonamento das mensagens. O objetivo é otimizar o escalonamento das mensagens de tal forma que a perda seja minimizada e as mensagens de menor prioridade também possam ser atendidas. Dois algoritmos são utilizados: o primeiro baseado na ordenação lexicográfica e o segundo no uso de funções barreira.

Este artigo é organizado como segue. Na Seção II, a abordagem tradicional e os algoritmos de precedência são apresentados. A Seção III introduz o conceito de Qualidade de Serviço Militar (MQoS) e do valor militar da informação. Nossas abordagens propostas são apresentadas na Seção IV. Os cenários e resultados da simulação estão descritos na Seção V. O trabalho finaliza na Seção VI com considerações finais.

\section{Abordagem TradicionAL}

A abordagem tradicional para classificação do tráfego se baseia em níveis de precedência [13] que identificam a ordem pelas quais as mensagens e/ou fluxos de informações devem ser atendidos. Atualmente, existem quatro níveis de precedência empregados nas Forças Armadas: 
- Urgentíssima (UU): tem precedência sobre todas as demais, interrompendo o processamento e transmissão de outras mensagens - $\left(P_{0}\right)$;

- Urgente (U): tem precedência sobre as demais de precedência mais baixa - $\left(P_{1}\right)$;

- Prioridade $(\mathrm{P})$ : precedência mais alta que se pode dar a mensagens administrativas - $\left(P_{2}\right)$;

- Rotina (R): todas as mensagens que a importância não justifique precedência mais elevada - $\left(P_{3}\right)$.

Nessa abordagem, o sistema possui quatro filas de prioridades e quando uma nova mensagem $i$ chega ao sistema ela é armazenada na fila correspondente. Para o próximo envio, será escalonada a mensagem armazenada na fila de maior precedência, mesmo que o prazo de validade tenha expirado. $\mathrm{O}$ envio de mensagens expiradas em uma rede saturada causa desperdício de recursos e leva a perda de outras mensagens que estão aguardando na fila.

Uma maneira direta de implementar os níveis da precedência acima seria utilizar um escalonador baseado no algoritmo Priority Queuing [12]. Entretanto, tal procedimento é ineficiente [4] e pode causar grande atraso ou perda nas mensagens de menor precedência, principalmente quando a taxa de chegada de mensagens de prioridade mais elevada é maior que a capacidade do canal.

\section{Qualidade de Serviço em Redes Militares}

Em redes comerciais, se não existe suficiente disponibilidade de recursos para o estabelecimento ou manutenção dos níveis de QoS para um determinado fluxo, uma solução é descartar o fluxo sem antes oferecer um serviço de qualidade inferior (degradação do nível de QoS).

Entretanto, como discutido em [8], em redes militares quando não existem recursos de rede disponíveis para suportar os níveis de QoS exigidos para todos os fluxos, àqueles que carregam informações críticas para uma missão devem ter preferência em relação aos menos importantes. Além disso, em redes sobrecarregadas é preferível reduzir os fluxos militares menos importantes em vez de automaticamente pará-los, a aplicação final deve decidir se o serviço oferecido é suficiente para continuação do fluxo. Por outro lado, a rede e não a aplicação final, deve decidir se e qual fluxo deve ser degradado. Finalmente, prioridades elevadas para determinados fluxos devem ser aplicadas somente por um tempo limitado definido pela doutrina.

A arquitetura de QoS proposta para redes comerciais conjuntamente com as características listadas anteriormente é denominada Qualidade de Serviço Militar (MQoS) conforme denominação encontrada em [8] e [1].

Os problemas da abordagem tradicional e o conceito de MQoS motivaram o desenvolvimento de mecanismos específicos para que as mensagens de menor precedência possam ser atendidas, mesmo na presença de mensagens mais importantes em determinadas situações, reduzindo assim a perda de mensagens de rotina. Diversos estudos estão sendo realizados para prover as redes militares de dispositivos que permitam que suas peculiaridades sejam atendidas e assim o provimento de MQoS.
Em [8] é proposta uma arquitetura de gerência e controle da rede para suportar os requisitos de MQoS de forma a atender as necessidades de uma rede de coalizão formada pela Austrália, Estados Unidas e Canadá. Tal arquitetura tem como objetivo criar um mecanismo que permita controlar como os fluxos são ajustados e quais recursos de rede serão necessários.

Em [1] é apresentada a proposta para uma interface padrão, denominada interface MQoS, com a finalidade de estabelecer a troca de informações entre a aplicação final e o framework apresentado em [8]. Nesse trabalho é apresentado também o conceito da prioridade final (PF) que é a prioridade de um determinado fluxo definida através do seu valor militar e são propostos trabalhos futuros visando o estudo de algoritmos viáveis para o cálculo da Prioridade Final.

Como pode ser observado em [1] são permitidas diferentes formas para se calcular o valor da $\mathrm{PF}$ e esta pode variar entre as redes que o fluxo trafegar, assim como dentro da própria rede ou domínio em momentos ou circunstâncias diferentes, como por exemplo tempos de crise e tempos de paz.

Essa flexibilidade em utilizar diversas políticas para o cálculo da PF é que permite o uso desse framework em diversas circunstâncias e não apenas em aplicações militares, ou seja, é onde reside a dualidade da aplicação.

Em [5] são propostas alterações no mecanismo de serviços diferenciados (DiffServ) para implementar Qualidade de Serviço nas redes militares.

\section{Algoritmos Propostos}

Para tentar minimizar os problemas citados na Seção II utilizando os conceitos de MQoS apresentados na Seção III, este artigo propõe dois escalonadores multi-critério com o objetivo de otimizar o uso dos escassos recursos encontrados geralmente em redes sem fio de baixo desempenho, e permitir uma coexistência mais justa das diferentes classes de precedência. Para cada escalonador um algoritmo irá calcular a prioridade final da mensagem para poder realizar o agendamento de tal forma a minimizar as perdas. $\mathrm{O}$ primeiro algoritmo apresentado utiliza os conceitos da ordenação lexicográfica [15], enquanto o segundo utiliza uma função barreira com o peso do numerador variando de acordo com os critérios de precedência e nível hierárquico. Os critérios considerados são: prazo de validade, precedência e nível hierárquico do emissor.

\section{A. Seqüência de Eventos}

Quatro tipos de evento podem ocorrer quando uma nova mensagem $i$ chega ao sistema, uma ação correspondente a cada evento deve ser realizada:

- Evento 1 - Chegada de uma nova mensagem $i$ e ausência de mensagens sendo transmitidas (sistema vazio);

- Se o tempo de envio $T_{i}$ é menor que o prazo de validade $E_{i}$, então enviar $i$;

- Evento 2 - Chegada de uma nova mensagem $i$, uma mensagem $j$ está sendo transmitida e o buffer está vazio;

- Se a soma do tempo de espera para terminar a transmissão de $j W_{j}$ e o tempo de envio $T_{i}$ para $i$ for menor que o prazo de validade $E_{i}$ de $i$, então armazenar $i$ no buffer; 
- Evento 3 - Chegada de uma nova mensagem $i$, uma mensagem está sendo transmitida e o buffer não está vazio;

- Primeiro deve ser verificado se o tempo de expiração da nova mensagem é maior que o tempo restante para o envio da mensagem atual. Caso contrário, a mensagem é prontamente descartada; - Se a soma do tempo de espera para terminar a transmissão de $j W_{j}$ e o tempo de envio $T_{i}$ para $i$ for menor que o prazo de validade $E_{i}$ de $i$, um algoritmo deverá ser empregado para tratar da nova configuração do sistema;

- Evento 4 - Término da transmissão e existência de mensagens no buffer.

- empregar algoritmo de escalonamento.

\section{B. Algoritmo Lexicográfico}

Nesta abordagem o algoritmo para calcular a Prioridade Final (PF) de cada mensagem utiliza a ordenação lexicográfica e leva em consideração todos os critérios definidos. Um exemplo natural deste tipo de ordenação é a forma como as palavras são ordenadas em um dicionário. Na matemática, é a ordenação do produto cartesiano de dois conjuntos A e B. Dados dois conjuntos $\mathrm{A}$ e $\mathrm{B}$, a ordenação lexicográfica do produto cartesiano $A \times B$ é definida como:

- Se $\left(a_{1}, b_{1}\right)$ e $\left(a_{2}, b_{2}\right)$ pertencem a $A \times B$, então $\left(a_{1}, b_{1}\right)<$ $\left(a_{2}, b_{2}\right)$ se e somente se:

$-a_{1}<a_{2}$, ou

- $a_{1}=a_{2}$ e $b_{1}<b_{2}$

Generalizando para uma seqüência de caracteres $A=$ $\left(a_{1}, a_{2}, \ldots, a_{k}\right)$ e $B=\left(b_{1}, b_{2}, \ldots, b_{k}\right), A<B$ se e somente se o primeiro $a_{i}$ no qual é diferente de $a_{i}$, seja menor que $b_{i}$, ou seja, uma palavra A aparecerá antes de uma palavra B se a letra $a_{i}$ aparecer antes da letra $b_{i}$ no alfabeto.

Aplicando a ordenação lexicográfica ao escalonador multicritério, cada elemento $a_{i}$ está associado a um critério definido anteriormente e então deve ser ordenado dentro deste critério.

A complexidade do algoritmo para o pior caso é $\mathrm{O}(\mathrm{n})$, quando sempre chega uma mensagem com menor PF que as existentes no buffer e é armazenada no final da fila. Entretanto, a probabilidade de ocorrer essa situação é muito baixa. $\mathrm{Na}$ média, a complexidade média do algoritmo fica em $\mathrm{O}(\log \mathrm{n})$.

1) Ordem dos critérios: Como o objetivo é que seja maximizado o atendimento das mensagens, ou seja, o número de mensagens que perderam a validade deve ser o menor possível, o primeiro critério a adotado para ordenar as mensagens foi o prazo de validade, as mensagens que estiverem mais próximas de expirar terão prioridade no atendimento.

Depois de ordenadas dentro dos prazos de validade, as mensagens serão ordenadas pelo critério da precedência. As mensagens de maior precedência devem ser atendidas prioritariamente desde que não acarrete em um aumento do número de mensagens expiradas.

Após as mensagens estarem ordenadas pela precedência, o próximo critério a ser utilizado é o do nível hierárquico do emissor. As seqüências de mensagens de mesmo nível de precedência que estiverem agrupadas serão reordenadas movendo as mensagens que possuírem maior nível hierárquico para o início da seqüência. Para essa movimentação da mensagem não pode haver um incremento no número de mensagem expiradas.

2) Aplicação do algoritmo ao evento $I V$-A da seção $I V$ $A$ : Chegada de uma nova mensagem $i$, uma mensagem está sendo transmitida e o buffer não está vazio. Será necessário a aplicação da ordenação multi-critério e para cada critério é estabelecido um objetivo a ser alcançado.

Após ser verificado a possibilidade de anteder a mensagem $i$ caso ela seja posicionada no primeiro lugar do buffer, devese aplicar o primeiro critério que será baseado no prazo de validade. Caso não seja possível antender na primeira posição, ou seja, o tempo de expiração da nova mensagem é maior que o tempo restante para o envio da mensagem atual, a nova mensagem $i$ deve ser descartada para evitar desperdício de processamento.

Inicialmente deverão ser encontradas todas as possíveis posições que a nova mensagem $i$ pode ocupar no sistema até a posição limite $k$ a partir da qual ela não poderá ser atendida.

$$
k \Leftarrow \operatorname{Max}(z)\left\{\left(W_{x}+\sum_{p=1}^{z} T_{p}+T_{i}\right)<E_{i}\right\}, z=1 \ldots n
$$

Sendo $W_{x}$ o tempo de espera para término da transmissão da mensagem $x, T_{p}$ o tempo de envio para cada mensagem, $T_{i}$ o tempo de envio da nova mensagem $i, E_{i}$ o prazo de validade de $i$ e $z$ a posição das mensagens no buffer. O conjunto $\left(S_{1}\right)$ de possíveis posições para $i$ será então $S_{1}=\{1 \ldots k\}$.

Ainda no critério do prazo de validade, deve-se checar se o atendimento de $i$ irá causar a expiração de uma mensagem antiga $j$ e guardar a posição da última expirada e a quantidade de mensagens, caso existam.

$$
\begin{array}{r}
j \leftarrow \operatorname{Max}(z)\left\{\left(W_{x}+\sum_{p=1}^{z} T_{p}+T_{i}\right)>E_{p}\right\}, z=1 \ldots n ; \quad \mathrm{e} \\
\forall\left(W_{x}+\sum_{p=1}^{z} T_{p}+T_{i}\right)>E_{p}, z=1 \ldots n \Rightarrow N_{j}+1
\end{array}
$$

Sendo $E_{p}$ o prazo de validade da mensagem $p$ existente no buffer e $N_{j}$ o número de mensagens que podem expirar com a inserção de $i$.

Com o valor da posição limite $k$ calculada, da posição da ultima mensagem $j$ e o número de mensagens expiradas $N_{j}$ calculadas, podemos ter três situações distintas:

1) Se $N_{j}=0$ então o conjunto de solução para esse critério será $S 1=\{1 \ldots k\}$; caso $k=n$, a mensagem $i$ poderá ser posicionada em qualquer lugar do buffer e pode-se passar o conjunto solução para o próximo critério;

2) Se $N_{j}=1$, duas situações podem ocorrer:

a) Se $k>j$, então $i$ pode ser posicionada após a última mensagem $j$ e o conjunto solução será

$$
S 1=\{j \ldots k\}
$$


b) Caso contrário, deve-se verificar qual a mensagem $(i$ ou $j$ ) tem menor valor (PF-PrioridadeFinal) de acordo com os próximos critérios:

i) Se $P F_{i}>P F_{j} \Rightarrow$ Descartar $j \rightarrow$ conjunto solução será $S 1=\{1 \ldots k\}$;

ii) Se $P F_{i}<P F_{j} \Rightarrow$ procurar uma mensagem $p$ no buffer tal que $P F_{i}>P F_{p}$ e que implique em $N r_{j}=0$.

Se houver, trocar a mensagem $i$ por $p$ no buffer e, recursivamente, procurar uma outra mensagem $q$ no buffer tal que $P F_{p}>P F_{q}$ até a de menor prioridade que seja descartada. Caso não exista mensagem $p$, descartar $i$.

Nessa situação o conjunto solução será a posição $p$ que foi substituída ou o próprio descarte não necessitando de passar para os próximos critérios.

Com este critério, a cada chegada de uma nova mensagem $i$ pode-se garantir que no máximo 1(uma) mensagem será descartada, porque a comparação é realizada com uma mensagem por vez apenas.

Após o primeiro critério, deve-se aplicar o critério de precedência $P_{i}$ para encontrar o novo conjunto de soluções $S 2$. Deve-se procurar dentro do conjunto de soluções $S 1$ as possíveis posições para $i$ comparando-se a precedencia das mensagens. A mensagem $i$ deve ser posicionada após a última mensagem $j$ de maior ou igual precedencia que $i$.

$$
S 2=\{p \ldots q\} \mid P_{p-1} \geq P_{i} \quad \text { e } \quad q \leq k
$$

O conjunto solução $S 2$ será aplicado ao terceiro critério - nível hierárquico do emissor $H_{i}$. De forma semelhante ao critério da precedência, deve-se procurar em $S 2$ as possíveis posições que $i$ pode ocupar de tal forma que ela seja posicionada após a última mensagem de maior ou igual nível hierárquico que $i$ e que será a sua posição final no buffer.

$$
S 3=\{r\} \mid H_{r-1} \geq H_{i} \quad \text { e } \quad r \leq q
$$

O buffer então estará ordenado de acordo com o grau de importância das mensagens e o escalonador pode enviar a primeira mensagem no buffer ao final de uma transmissão.

Se durante a aplicação de algum critério resultar uma única solução o algoritmo pára e armazena $i$ na posição indicada.

3) Aplicação do algoritmo ao evento 4 da seção IV-A: Selecionar a próxima mensagem no buffer ordenado, verificar se é possível antedê-la e, caso seja possível, enviá-la. Caso contrário a mensagem será descartada e selecionada a próxima mensangem no buffer.

\section{Algoritmo Função Barreira}

A segunda abordagem propõe a utilização de métodos de barreira que são métodos de penalidade, em geral, empregados para resolver problemas com restrições de desigualdade. Dois tipos de função são bastante conhecidas na literatura [9] [6], a função barreira logarítmica e a função barreira inversa, esta última foi a adotada neste trabalho, sendo definida por

$$
x \in \Re^{n} \mapsto f(x)=\frac{\kappa}{g(x)}
$$

A função barreira será responsável por mensurar o valor da Prioridade Final de cada mensagem. Para cada mensagem será aplicada a função e aquela que resultar maior valor será a selecionada para envio no evento IV-A. Os critérios aplicados a função foram definidos da seguinte forma:

- $g(x)$ foi definida em função do prazo de validade e o tempo de espera da mensagem no sistema,

$$
g\left(W_{j}\right)=E_{j}-W_{j}
$$

onde $E_{j}$ é o prazo de validade da mensagem $j$ no buffer e $W_{j}$ o tempo que a mensagem $j$ está armazenada no buffer;

- Os critérios de nível hierárquico e precedência foram utilizados para determinar um peso $\delta_{p n} \mid p=$ $P_{0} \ldots P_{3}$ e $h=H_{0} \ldots H_{15}$, ou seja, o valor de $\kappa$ aplicado ao numerador da função de tal forma que as mensagens de maior (menor) nível hierárquico e precedência possuem maior (menor) peso $\delta_{00}=64\left(\delta_{315}=1\right)$.

Aplicando os critérios à função barreira, esta fica definida por

$$
\operatorname{Max}\left\{f\left(W_{j}\right)=\frac{\delta p_{j} h_{j}}{E_{j}-W_{j}}\right\}
$$

Assim, pode ser concluido que a Prioridade Final cresce conforme a mensagem se aproxima de expirar e esse crescimento é mais acentuado para as mensagens de maior precedência e nível hierárquico devido ao peso $\delta$ maior.

Como o algorimo barreira necessita fazer uma busca em toda a fila existente no buffer, assim a complexidade do algoritmo é $\mathrm{O}(\mathrm{n})$.

1) Aplicação do algoritmo ao evento IV-A da seção IV-A: Neste método, quando chega uma nova mensagem $i$, existe uma mensagem sendo transmitida e o buffer não está vazio, os passos a serem realizados serão: verificar a possibilidade de atendimento caso a mensagem seja a próxima a ser atendida e, sendo possível, armazená-la no buffer na última posição da fila. Caso o resultado da verificação seja a impossibilidade de atendimento, a mensagem $i$ deve ser descartada.

2) Aplicação do algoritmo ao evento 4 da seção $I V$-A: Enquanto uma mensagem está sendo transmitida, o algoritmo estará sendo executado com a finalidade de encontrar a próxima mensagem a ser enviada.

Para encontrá-la, a equação (8) será aplicada a todas as mensagens existentes no buffer e a que possuir maior PF será a próxima a ser enviada. Porém, antes de enviá-la devese verificar se ainda é possível realizar o atendimento para evitar desperdício de recursos. Caso não possa, esta deverá ser descartada e deve-se verificar a próxima mensagem com maior PF até que uma delas possa ser atendida.

$\operatorname{Max}(z)\left\{\frac{\delta_{i}}{E_{i}-W_{i}}\right\}, i=1 \ldots m, \quad$ e $\quad W_{z}<E_{z} \Rightarrow$ Enviar $z$

\section{Simulação}

\section{A. Cenários}

Para a realização da simulação foi implementado um simulador de eventos discretos e para o cenário de simulação a 
topologia utilizada foi a mesma descrita em [3] com uma ligação ponto a ponto entre duas estações distando aproximadamente $2900 \mathrm{~km}$, interligadas por um canal HF, sem compartilhamento do meio, com capacidade nominal de 9600 bps, latência de $10 \mathrm{~ms}$, tráfego exponencial, o tamanho médio do arquivo foi de $10 \mathrm{~KB}$ e buffer ilimitado.

Para a troca de mensagens entre as máquinas pode ser considerado o uso de servidores de mensagens que implementem qualquer tipo de troca de mensagens como SMTP - Simple Mail Transfer Protocol, HMTP - HF Email Transfer Protocol [10] ou MMHS - Military Messages Handling Systems [11].

Os cenários utilizados para as simulações representaram ambientes com baixa carga $(\rho \leq 0,5)$, média carga $(0,5<$ $\rho \geq 0,8)$ e alta carga $(0,8<\rho \leq 1,5)$. Para cada carga foram realizadas simulações com prazo de validade fixo apresentados na Tabela I e a taxa de chegadas de cada classe balanceada e não balanceada.

TABELA I

PRAZO DE VALIDADE

\begin{tabular}{|l|c|}
\hline Precedência & Tempo (s) \\
\hline Urgentíssima & 600 \\
Urgente & 3600 \\
Prioridade & 21600 \\
Rotina & 84600 \\
\hline
\end{tabular}

A taxa de chegada das mensagens para cada precedência estará balanceada quando $\lambda_{P_{i}}=\lambda / n$, sendo $n$ o número de classes de precedência empregadas na simulação. Para a carga não balanceada as razões adotadas foram:

- $\lambda_{P_{0}} / \lambda_{P_{1}}=1 / 2$

- $\lambda_{P_{1}} / \lambda_{P_{2}}=1 / 2$

- $\lambda_{P_{2}} / \lambda_{P_{3}}=1 / 2$

Os tempos de operação utilizados para as simulações estão descritos na Tabela II.

TABELA II

NÚMERO DE MENSAGENS

\begin{tabular}{|l|c|}
\hline Tempo de operação & Quantidade de mensagens \\
\hline 1 dia & 10125 \\
1 semana & 70875 \\
2 semanas & 141750 \\
3 semanas & 212625 \\
4 semanas & 283500 \\
\hline
\end{tabular}

O intervalo de confiança da simulação ficou em torno de $1 \%$ para os parâmetros avaliados com probabilidade entre $95 \%$ a 99\%. Para atingir esse intervalo de confiança, foi necessário executar 3.000 simulações para os cenários de menor duração (1 dia) e 500 simulações para os de maior prazo (4 semanas).

\section{B. Resultados}

Os resultados podem ser separados em dois grandes grupos com relação a taxa de chegada de mensagens: $\lambda<1,0$ e $\lambda>1,0$. Para o primeiro caso as abordagens tiveram o mesmo desempenho, com perda de mensagens igual a zero e tempo médio de serviço semelhante. Para o segundo caso é que surgiram mensagens perdidas no sistema e pode-se comparar o desempenho dos algoritmos.
1) 1 até 4 semanas de operação e carga balanceada: Analisando os cenários no qual as operações tem duração igual ou superior a uma semana e carga balanceada, o algoritmo lexicográfico apresentou um desempenho superior ao das outras abordagens com a redução significativa das mensagens expiradas, apresentando redução das perdas em relação ao algoritmo de precedência, no melhor caso, de $76 \%$ quando se utilizou $\lambda=1,1$ e com tempo de operação de 2,3 ou 4 semanas e, no pior caso, média de $48 \%$, com $\lambda=1,3$. Para este algoritmo não houve variação significativa no número de mensagens perdidas com o aumento no tempo de operação conforme pode ser verificado na figura 1 que apresenta uma comparação da perda das mensagens, em relação ao tempo de operação para uma taxa $\lambda=1,5$. Para o método barreira houve um leve incremento conforme o tempo de operação aumenta.

O desempenho para o algoritmo da função barreira mostrouse intermediário em relação as outras duas abordagens na análise da redução da perda total do número de mensagens conforme pode ser verificado na figura 2 .

Analisando as figuras 2 e 3 pode-se observar que além da redução do número total de mensagens expiradas, as mensagens de menor precedência também tiveram reduzidas suas perdas, porém verificou-se que as mensagens de maior precedência passaram a apresentar perdas, o que não ocorria na abordagem tradicional. Nesse aspecto o desempenho do algoritmo de barreira foi muito inferior com perdas de mensanges urgentíssimas quase três vezes superior ao algoritmo lexicográfico em alguns cenários.

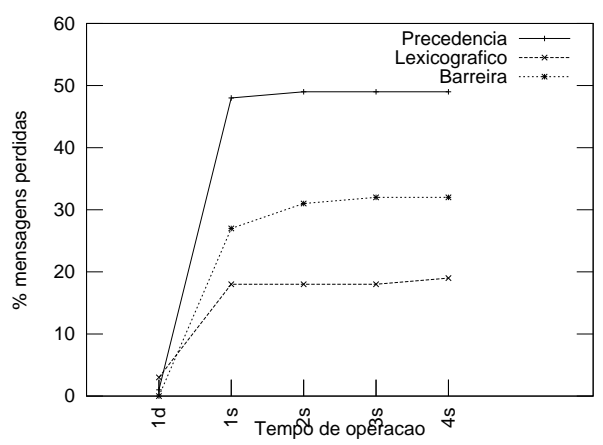

Fig. 1. Tempo Operação x Perda Total - Carga Balanceada e $\lambda=1,5$.

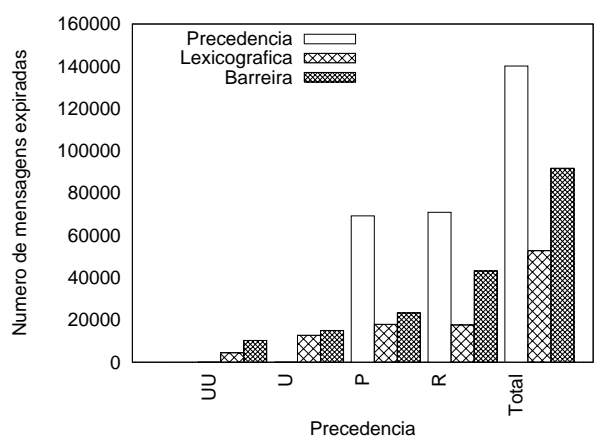

Fig. 2. 4 Semanas de operação, carga balanceada e $\lambda=1,5$.

2) 1 até 4 semanas de operação e carga não balanceada: A análise do comportamento com carga não balanceada foi 
semelhante à carga balanceada, com o algoritmo lexicográfico reduzindo consideravelmente as perdas totais dos sistemas na ordem de $87 \%$ com $\lambda=1,1$ no melhor caso e o algoritmo de função barreira apresentando desempenho intermediário em relação as outras abordagens como pode ser verificado na figura 3.

Porém, para uma semana de operação e $\lambda=1,1$ e 1,2 o desempenho do método barreira foi superior ao método lexicográfico como pode ser observado na figura 4 para taxa $\lambda=1,1$ e figura 5 para taxa $\lambda=1,2$.

O tempo médio de atendimento das mensagens aumentou consideravelmente nas duas abordagens propostas, com aumento expressivo no método barreira. Esse efeito reflete o fato do primeiro critério de ordenação ser o prazo de validade e acarretando que as mensagens sejam enviadas já próximas de expirar.

Apesar de não existirem sistemas com buffer ilimitado, verificou-se que no período de 4 semanas de operação permaneciam armazenadas na ordem de 1.200 mensagens. Considerando que o tamanho médio das mensagens enviadas foi de $10 \mathrm{~KB}$, seria necessário um buffer de aproximadamente 12 MB para que o comportamento seja similar ao do emprego em buffer infinito, o que não é difícil de supor sistemas com essa capacidade.

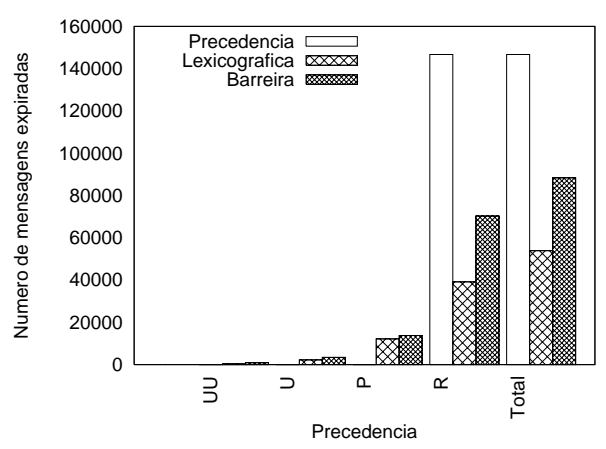

Fig. 3. 4 Semanas de operação, carga não balanceada e $\lambda=1,5$

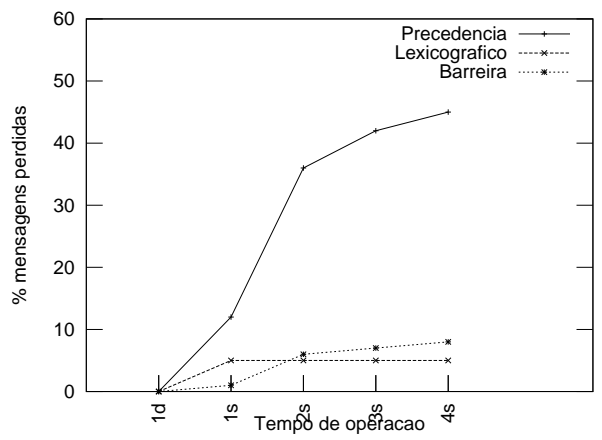

Fig. 4. Tempo Operação x Perda Total - Carga Não Balanceada e $\lambda=1,1$.

\section{CONSIDERAÇÕES FINAIS}

Neste trabalho foram propostos dois algoritmos para escalonamento de mensagens, um baseado na ordenação lexicográfica e outro no método de barreira. O algoritmo

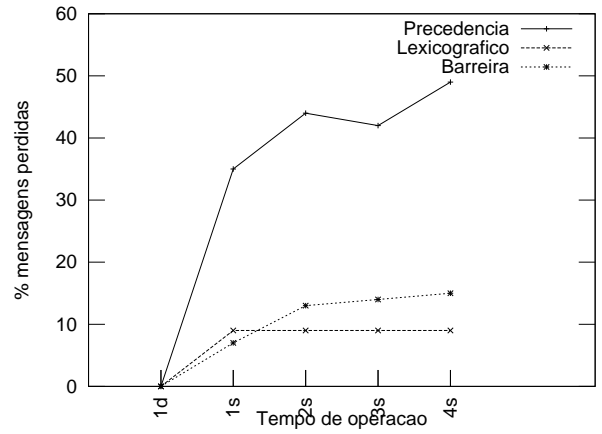

Fig. 5. Tempo Operação x Tempo Total - Carga Não Balanceada e $\lambda=1,2$.

de ordenação lexicográfica mostrou-se mais eficiente para operações com tempo superior a uma semana. Ambos foram capazes de minimizar as perdas de mensagens em um sistema de mensagens quando comparado com a abordagem tradicional. Os algoritmos apresentaram alguns problemas como a perda de mensagens de precedência elevada assim como o aumento do tempo médio na fila. Trabalhos futuros podem ser realizados com o intuito de reduzir o efeito desses problemas, além de serem estudados novos algoritmos multicritério e compará-los com as abordagens apresentadas. Outra análise deve ser realizada utilizando-se buffers finitos associados a mecanismos de gerência.

\section{AGRADECIMENTOS}

Os autores gostariam de agradecer todo o apoio recebido pelo Instituto Militar de Engenharia (IME) e pela Coordenação de Aperfeiçoamento de Pessoal de Nível Superior (CAPES) sem os quais este trabalho não seria possível.

\section{REFERÊNCIAS}

[1] P. Blackmore, P. George, and M. Kwiatkowski. A quality of service interface for military applications. MILCOM 00, 2000.

[2] W. Blair. Improving the performance of a high frequency radio message network. Technical report, Department of Defence of Australia, 2000.

[3] M. B. T. Dantas. Desempenho de procolos tcp e de camada de enlace para canal hf. Master's thesis, Instituto Militar de Engenharia, 2006.

[4] W. D. I. e K. J. Pitt. Information value information based resource management of the defense information systems network. Technical report, The Mitre Corporation.

[5] M. K. e M. Elliot. Using router diffserv mechanisms to implement military qos. MILCOM 03, 2003.

[6] R. F. e M. J. D. Powell. A Method for Nonlinear Constraints in Minimizations Problems in Optimization. 1986.

[7] N. K. e P. Blackmore. Multimedia services in a tactical environment. MILCOM 96, 1996.

[8] M. K. e P. George. A network control and management framework supporting military quality of service. MILCOM 99, 1999.

[9] J. N. e S. J. Wright. Numerical Optimization. Springer Verlag, 1999.

[10] V. Jodalen, A. Eggen, B. Solberg, and O. Gronnerud. Military messaging in ip networks using hf links. IEEE Communications Magazine, pages 98-104, novembro de 2004.

[11] V. Jodalen, A. Eggen, B. Solberg, and O. Gronnerud. Performance testing of stanag 4406 (military messaging) using ip over hf. Technical report, Norwegian Defence Research Establishment, 2005.

[12] L. Kleinrock. Queueing Systems: Computer Applicationss, volume II. Wiley Interscience, 1976.

[13] The Mitre Corporation. Dinamic Precedence for military IP networks. MILCOM 00, 2000.

[14] http://www.defesacivil.gov.br/rener/index.asp.

[15] A. V. Zykina. A Lexicographic Optimization Algorithm. Omsk State Technical University, 2003. 